\title{
Effects of supplemental progesterone after artificial insemination on expression of interferon-stimulated genes and fertility in dairy cows
}

\author{
P. L. J. Monteiro Jr., ${ }^{*} \dagger$ E. S. Ribeiro, ${ }^{\star}$ R. P. Maciel, ${ }^{*}$ A. L. G. Dias, ${ }^{*}$ E. Solé Jr., ${ }^{*}$ F. S. Lima, ${ }^{*}$ R. S. Bisinotto, ${ }^{*}$ \\ W. W. Thatcher, ${ }^{*}$ R. Sartori, $†$ and J. E. P. Santos ${ }^{* 1}$ \\ *Department of Animal Sciences, University of Florida, Gainesville 32611 \\ †Department of Animal Science, University of São Paulo, Piracicaba, SP 13418-900 Brazil
}

\begin{abstract}
The objectives of the current study were to evaluate the effects of supplemental progesterone after artificial insemination (AI) on expression of IFN-stimulated genes (ISG) in blood leukocytes and fertility in lactating dairy cows. Weekly cohorts of Holstein cows were blocked by parity (575 primiparous and 923 multiparous) and method of insemination (timed AI or AI on estrus) and allocated randomly within each block to untreated controls, a controlled internal drug release (CIDR) containing $1.38 \mathrm{~g}$ of progesterone from $\mathrm{d} 4$ to 18 after AI (CIDR4), or a CIDR on d 4 and another on d 7 after AI and both removed on d 18 (CIDR4+7). Blood was sampled to quantify progesterone concentrations in plasma and mRNA expression in leukocytes for the ubiquitin-like IFN-stimulated gene $15-\mathrm{kDa}$ protein (ISG15) and receptor transporter protein-4 (RTP4) genes. Pregnancy was diagnosed on d $34 \pm 3$ and $62 \pm 3$ after AI. Treatment increased progesterone concentrations between d 5 and 18 after AI in a dosedependent manner (control $=3.42$, CIDR $4=4.97$, and CIDR $4+7=5.46 \mathrm{ng} / \mathrm{mL})$. Cows supplemented with progesterone tended to have increased luteolysis by $\mathrm{d}$ 19 after AI (control = 17.2; CIDR4 = 29.1; CIDR4+7 $=30.2 \%$ ), which resulted in a shorter AI interval for those reinseminated after study d 18. Pregnancy upregulated expression of ISG in leukocytes on d 19 of gestation, but supplementing progesterone did not increase mRNA abundance for ISG15 and RTP4 on d 16 after insemination and tended to reduce mRNA expression on d 19 after AI. For RTP 4 on d 19, the negative effect of supplemental progesterone was observed only in the nonpregnant cows. No overall effect of treatment was observed on pregnancy per AI on d 62 after insemination and averaged 28.6, 32.7, and 29.5\% for control, CIDR4, and CIDR4+7, respectively. Interestingly, an interaction between level of supplemental progesterone
\end{abstract}

Received December 4, 2013

Accepted April 24, 2014.

${ }^{1}$ Corresponding author: jepsantos@ufl.edu and method of AI was observed for pregnancy per AI. For cows receiving exogenous progesterone, the lower supplementation with CIDR4 increased pregnancy per AI on d 62 in cows inseminated following timed AI $($ CIDR $4=39.2$; CIDR $4+7=27.5 \%)$; in those inseminated following detection of estrus, however, the use of a second insert on $\mathrm{d} 7$ resulted in greater pregnancy per AI $($ CIDR $4=26.9$; CIDR $4+7=31.5 \%)$. Pregnancy loss did not differ among treatments. Supplemental progesterone post-AI using a single intravaginal insert on d 4 was beneficial to pregnancy in cows inseminated following timed AI, but incremental progesterone with a second insert on d 7 did not improve fertility of dairy cows.

Key words: dairy cow, interferon-stimulated gene, progesterone, reproduction

\section{INTRODUCTION}

Progesterone is pivotal for successful pregnancy in ruminants (Spencer et al., 2007), and lactating dairy cows are known to have reduced systemic concentrations of progesterone during diestrus compared with dairy heifers (Sartori et al., 2004). It is thought that inadequate progesterone concentrations during early development of the conceptus might be one of the reasons for reduced fertility observed in high-producing dairy cows (Wiltbank et al., 2011), in part because catabolism of steroids increases with increased feed intake associated with high production (Parr et al., 1993; Wiltbank et al., 2011). In fact, supplemental progesterone after AI from an exogenous source (Stevenson et al., 2007; Wiltbank et al., 2011) resulted in small increases in pregnancy per AI (P/AI). Compared with untreated controls, beef heifers treated with exogenous progesterone starting on $\mathrm{d} 3$ of the estrous cycle had a larger conceptus on d 17 (Carter et al., 2008, Clemente et al., 2009). Supplementing progesterone post-AI increased concentrations of IFN- $\tau$ in the uterine lumen (Mann et al., 2006), which reflects the expanded elongation of the trophectoderm from the conceptus of cows with increased concentrations of progesterone (Mann et al., 2006; Clemente et al., 2009). 
Timed AI protocols result in variable sizes of ovulatory follicles in dairy cows (Souza et al., 2007; Santos et al., 2010). Induction of ovulation of small follicles results in reduced P/AI in beef (Perry et al., 2005) and dairy cows (Souza et al., 2007), and increased risk of pregnancy loss (Perry et al., 2005). Embryo quality in cows synchronized for timed AI is of equal or better quality than that of cows inseminated after detected estrus (Cerri et al., 2009b); however, cows subjected to timed AI protocols that are induced to ovulate small follicles have a small resulting corpus luteum $(\mathbf{C L})$ with reduced ability to increase peripheral concentrations of progesterone (Vasconcelos et al., 2001), thereby potentially reducing P/AI (Parr et al., 2012). Therefore, benefits from progesterone supplementation might be greater in cows inseminated following timed AI programs.

Interferon- $\tau$ secreted by the trophectoderm of the conceptus is the main signal for pregnancy recognition, initiating the process to block the luteolytic cascade and preventing the demise of the CL (Meyer et al., 1995). In the bovine conceptus, mRNA for IFN- $\tau$ is detected in trophoblast on d 12 of gestation, with peaks occurring between d 15 and 16 (Farin et al., 1990). Interferon gene mRNA expression in conceptuses is activated with the developmental stage of the blastocyst, and progesterone plays a pivotal role in stimulating conceptus development in utero (Clemente et al., 2009). In general, it is thought that stimulation of embryo development by an early rise in progesterone should benefit fertility (Stronge et al., 2005; Parr et al., 2012), possibly because of advancing conceptus development. Nevertheless, fertility responses to exogenous progesterone seem to be greater when supplementation occurs before (Bisinotto et al., 2013) rather than after (Stevenson et al., 2007) AI. In most studies with post-AI progesterone supplementation to lactating dairy cows, no apparent attempt was made to mimic the normal rise in progesterone observed in heifers, which is greater and faster than that of cows (Sartori et al., 2004). An exception is the recent work by Nascimento et al. (2013), in which lactating dairy cows receiving and injection of 3,300 IU of human chorionic gonadotropin (hCG) on d 5, concurrent with insertion of a controlled internal drug release containing progesterone, had progesterone profiles during diestrus similar to those of dairy heifers. The authors speculated that such manipulation mimicking the progesterone concentrations in heifers might benefit fertility of lactating dairy cows. Therefore, it is possible that the limited benefit to post-AI progesterone supplementation on pregnancy might be the result of insufficient supplementation or inability to mimic the continuous rise and incremental difference during diestrus between groups known to have low fertility (lactating cows) and those of high fertility (heifers).
Interferon- $\tau$ binds type I IFN receptor (Roberts et al., 1999), which leads to downregulation of oxytocin receptor expression on superficial glandular and luminal epithelia in sheep (Roberts et al., 1999; Spencer et al., 2007), and this mechanism is thought to be similar among all domestic ruminants. The downregulation of oxytocin receptors ultimately inhibits pulsatile release of $\mathrm{PGF}_{2 \alpha}$ responsible for the demise of the CL (Meyer et al., 1995; Spencer et al., 2007). Production of IFN- $\tau$ by the conceptus induces IFN-stimulated genes (ISG) in the endometrium, such as myxovirus (influenza virus) resistance $1(M x 1)$ and receptor transporter protein 4 (RTP4; Hicks et al., 2003; Gifford et al., 2008). Blood leukocytes harvested on d 16 or 19 after AI had increased expression of the ISG ubiquitin-like IFN-stimulated gene $15-\mathrm{kDa}$ protein (IGS15), Mx1, Mx2, and RTP4 (Gifford et al., 2007; Ribeiro et al., 2014), and leukocyte mRNA for ISG was correlated with the amount of IFN- $\tau$ in the uterus (Matsuyama et al., 2012). Interestingly, stimulation of conceptus development during pre- and peri-implantation resulted in increased expression of ISG in blood leukocytes and increased P/AI in lactating dairy cows (Ribeiro et al., 2014).

The main hypothesis of the present study was that supplemental progesterone starting during metestrus would improve $\mathrm{P} / \mathrm{AI}$ in dairy cows, particularly in those synchronized for timed AI. It was thought that supplemental progesterone would increase concentrations of progesterone in plasma in a dose-dependent manner, which would stimulate mRNA abundance for ISG in peripheral blood leukocytes, as a measure of improved embryonic-maternal crosstalk, thereby supporting improved pregnancy. Therefore, the main objective of the present study was to investigate the effects of supplemental progesterone starting during metestrus on $\mathrm{P} / \mathrm{AI}$ when cows are inseminated following detected estrus or timed AI. Additional objectives were to characterize concentrations of progesterone in plasma, luteal lifespan, and abundance of mRNA for ISG in leukocytes in lactating dairy cows supplemented with progesterone.

\section{MATERIALS AND METHODS}

All procedures involving animals in this study were approved by the University of Florida Non-Regulatory Animal Research Committee.

\section{Cows, Housing, and Diets}

Our study was conducted on a dairy farm in central Florida milking 5,400 cows with a yearly rolling herd average milk yield of $10,700 \mathrm{~kg}$ during the study period. Weekly cohorts of cows were enrolled during 7 consecu- 
tive weeks and all inseminations were performed from March 25 to May 9, 2013. Primiparous $(\mathrm{n}=575)$ and multiparous $(\mathrm{n}=923)$ cows were housed separately in freestall barns equipped with sprinklers and fans. Cows received the same TMR to meet or exceed the nutrient requirements for a lactating Holstein cow producing 45 $\mathrm{kg}$ of milk/d with $3.5 \%$ fat and $3.1 \%$ true protein when DM intake was $24 \mathrm{~kg} / \mathrm{d}$ (NRC, 2001). Diet consisted of rye grass silage, corn silage, corn earlage, ground corn, citrus pulp, solvent-extracted soybean meal, expeller soybean meal, corn gluten feed, molasses, minerals, and vitamins. Cows were fed twice and milked thrice daily.

\section{Sample Size and Experimental Design}

The sample size was calculated using the Minitab statistical software (version 16.2.4; Minitab Inc., State College, PA) using a one-sided test to provide sufficient experimental units to detect statistical significance $(\alpha=0.05 ; \beta=0.20)$ when $\mathrm{P} / \mathrm{AI}$ increased 6 percentage units (e.g., 30 vs. $36 \%$ ) with supplemental progesterone. Approximately 488 cows per treatment were deemed necessary, for a total of 1,464. Because of potential attrition during the study, a total of 1,498 were randomly assigned to treatments in a randomized complete block design. Two blocking criteria were used before randomization to treatments, method of AI (as detected estrus or timed AI) and parity (as primiparous or multiparous). Four randomization forms were pre-prepared, one for each combination of blocks: primiparous inseminated at detected estrus, primiparous inseminated at a fixed time, multiparous inseminated at detected estrus, and multiparous inseminated at a fixed time. Within each form, treatments were randomized within a block containing 3 cows such that each block had each of the 3 treatments represented. Cows were enrolled in sequence of availability as they were found in the farm on d 4 after AI in 1 of the 4 forms according to the blocking criteria, and day of insemination was considered study d 0 .

\section{Treatments and Reproductive Program}

Treatments were no supplemental progesterone (control; $\mathrm{n}=499)$; a single controlled internal drug release (CIDR; Eazi-Breed CIDR Cattle Insert, Zoetis, Madison, NJ) insert containing $1.38 \mathrm{~g}$ of progesterone administered on d 4 (CIDR4; $\mathrm{n}=504)$ after $\mathrm{AI}$ and retained until d 18 after AI; or 2 CIDR, with one administered on d 4 and another on d 7 after AI (CIDR4+7; n = 495) and both retained until d 18 after AI (Figure 1).

At first AI, all cows underwent a presynchronization program receiving 2 treatments of $25 \mathrm{mg}$ of $\mathrm{PGF}_{2 \alpha}$ each $(5 \mathrm{~mL}$ of Lutalyse sterile solution, $5 \mathrm{mg} / \mathrm{mL}$ of dinoprost as tromethamine salt; Zoetis) on d $43 \pm 3$ and $57 \pm 3$ postpartum. After the second $\mathrm{PGF}_{2 \alpha}$, cows were eligible to be inseminated if detected in estrus. Cows not identified in estrus by d $69 \pm 3$ postpartum were enrolled in a 5-d timed AI protocol [d $69 \mathrm{GnRH}$ (2 mL of Cystorelin; gonadorelin diacetate tetrahydrate equivalent to $43 \mu \mathrm{g}$ of gonadorelin/mL; Merial Ltd., Duluth, GA), d 74 and $75 \mathrm{PGF}_{2 \alpha}$, d $77 \mathrm{GnRH}$ and timed AI]. All cows not returning to estrus spontaneously received in advance an injection of $\mathrm{GnRH}$ injection for pre-enrollment for resynchronization on d $29 \pm 3$ after AI. Cows diagnosed nonpregnant on d $34 \pm 3$ after AI resumed the 5-d timed AI protocol, and timed AI was performed on d $37 \pm 3 \mathrm{~d}$ after the previous insemination. Throughout the study, after 57 DIM, cows had their tailheads painted using paintsticks (All-Weather Paintstik; LA-CO Industries Inc., Chicago, IL), and detection of estrus was evaluated daily, in the morning, based on removal of the tail paint. Cows identified in estrus were inseminated on the same morning.

\section{Blood Sampling and Analysis of Progesterone in Plasma}

Blood was sampled from a subset of 20 randomly selected blocks of cows (60 cows), 20 controls, 20 CIDR4, and 20 CIDR $4+7$ on study d 4, immediately before progesterone administration, and then again in the mornings of d 5, 7 (immediately before placement of the second progesterone insert in CIDR4+7), 8, 11, $14,16,18$, and 19. A second subset of 60 randomly selected blocks of cows were also sampled, 60 controls, 60 CIDR4, and 60 CIDR4+7, on study d 8, 16, and 19.

Blood was sampled by puncture of the coccygeal vein or artery into evacuated tubes containing $\mathrm{K}_{2}$ EDTA (Vacutainer, Becton Dickinson, Franklin Lakes, NJ). Immediately upon collection, tubes with blood were placed in ice and kept refrigerated until transported to the laboratory within 4 to $5 \mathrm{~h}$ for processing. Blood tubes were centrifuged at $1,500 \times g$ for $15 \mathrm{~min}$ at $4^{\circ} \mathrm{C}$ for plasma separation. Aliquots of plasma were frozen at $-20^{\circ} \mathrm{C}$ until assayed. Concentrations of progesterone were analyzed in plasma by RIA using a commercial kit (Coat-a-Count, Siemens Healthcare Diagnostics, Los Angeles, CA). Three assays were performed and the sensitivity of assays 1, 2, and 3 were at least $0.05 \mathrm{ng} /$ $\mathrm{mL}$ when calculated as $2 \mathrm{SD}$ below the mean counts per minute at maximum binding. Samples with low and moderate concentrations of progesterone, 1.3 and 4.0 $\mathrm{ng} / \mathrm{mL}$, respectively, were incorporated into each assay multiple times for quality control and for calculation of intra- and interassay CV. The intraassay CV for the low and moderate progesterone samples were, respectively, 8.3 and $3.5 \%$ in assay $1,4.7$ and $5.1 \%$ in assay 2 , and 


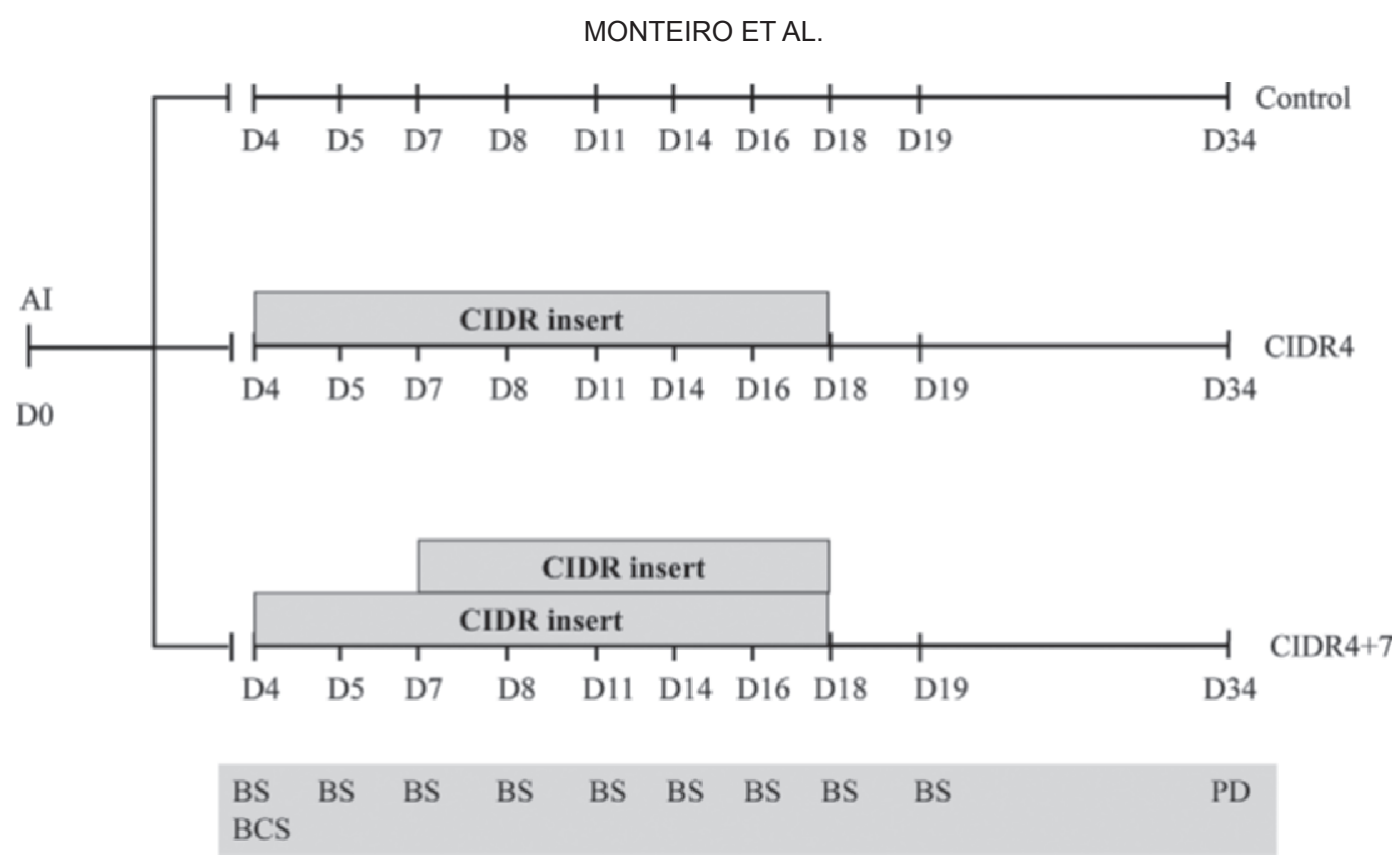

Figure 1. Diagram of activities for the study. Study d 0 is the day of insemination. Control = cows received no supplemental progesterone $(\mathrm{n}=492) ;$ CIDR $4=$ cows received a controlled internal drug-release (CIDR) insert containing progesterone from $\mathrm{d} 4$ to 18 ( $\mathrm{n}=492) ;$ CIDR $4+7$ $=$ cows received a CIDR insert containing progesterone on $\mathrm{d} 4$ and another on $\mathrm{d} 7$, and they were both removed on $\mathrm{d} 18(\mathrm{n}=484)$. BS $=$ blood sampled from a subset of 80 blocks of cows $(\mathrm{n}=240)$ and analyzed for progesterone concentrations on $\mathrm{d} 8,16$, and 19 , and leukocytes isolated and mRNA quantified for IFN-stimulated genes on d 16 and 19. Another subset of 20 blocks of cows $(\mathrm{n}=60)$ had blood sampled from d 4 to 19. $\mathrm{PD}=$ pregnancy diagnosis.

3.7 and $4.0 \%$ in assay 3. The interassay CV for the low and moderate samples were 1.1 and $1.4 \%$, respectively.

\section{Leukocyte Isolation and mRNA Extraction}

Blood sampled on d 16 and 19 from 58 blocks of cows from which progesterone concentrations were measured were also used for leukocyte isolation as described by Ribeiro et al. (2014). The pellets of isolated leukocytes were suspended with $0.8 \mathrm{~mL}$ of Trizol (Molecular Research Center Inc., Cincinnati, $\mathrm{OH}$ ), transferred to microcentrifuge tubes and stored at $-80^{\circ} \mathrm{C}$ until RNA extraction.

On the day of RNA extraction, samples were removed from the $-80^{\circ} \mathrm{C}$ freezer and $200 \mu \mathrm{L}$ of chloroform were added for each $1 \mathrm{~mL}$ of solution to reach a final concentration of $20 \%$. The microcentrifuge tubes were homogenized vigorously by hand for $15 \mathrm{~s}$ and incubated at room temperature for $3 \mathrm{~min}$. Tubes were centrifuged at $12,000 \times \mathrm{g}$ for $15 \mathrm{~min}$ at $4^{\circ} \mathrm{C}$ for removal of the upper aqueous solution containing RNA. Subsequent RNA extraction was performed using a commercial kit (Purelink RNA Mini Kit, Cat. No. 12183018A, Life Technologies, Carlsbad, CA) according to the manufacturer's instructions.

\section{Real-Time $q P C R$}

Isolated RNA was evaluated for concentration and purity using a NanoDrop 2000 spectrophotometer
(Thermo Scientific, Rockford, IL). Subsequently, the samples were incubated with DNAase (DNAase I, Cat. No.M0303, New England BioLabs Inc., Ipswich, MA) for 30 min at $37^{\circ} \mathrm{C}$ to remove genomic DNA then heatdenatured at $75^{\circ} \mathrm{C}$ for $15 \mathrm{~min}$. A total of $250 \mathrm{ng}$ of RNA was reverse transcribed to cDNA using a commercial kit (High-capacity cDNA Reverse Transcription Kit, Cat. No. 4368813, Applied Biosystems, Foster City, CA) following manufacturer's instructions. Real-time quantitative PCR was performed using SYBR Green PCR Master Mix (Cat. No. 4385614, Applied Biosystems) and the ABI 7300 Real Time PCR System (Applied Biosystems). After an initial activation at $60^{\circ} \mathrm{C}$ for $2 \mathrm{~min}$ followed by denaturation at $95^{\circ} \mathrm{C}$ for $10 \mathrm{~min}$, the amplification protocol followed 40 cycles of $95^{\circ} \mathrm{C}$ for $15 \mathrm{~s}$ and $60^{\circ} \mathrm{C}$ for $1 \mathrm{~min}$. Each sample was evaluated in triplicate, and the specificity for amplification was verified by melting curve analysis. Four genes were investigated (Table 1), including the 2 reference genes, $\beta$-actin $(A C T B)$ and ribosomal protein L19 (RPL19), and 2 target genes, ISG15 and RTP4.

\section{Pregnancy Diagnosis and Calculation of Reproductive Responses}

Pregnancy was diagnosed by transrectal ultrasonography on d $34 \pm 3$ after AI. The presence of an amniotic vesicle containing an embryo with a heartbeat was used as determinant of pregnancy. Pregnant cows on d 
Table 1. Gene, primer orientation, primer sequence $\left(5^{\prime}\right.$ to $\left.3^{\prime}\right)$, and National Center for Biotechnology Information (NCBI) accession number and sequence for primers used in real-time quantitative PCR assays

\begin{tabular}{llll}
\hline Gene & Primer & Sequence $\left(5^{\prime}\right.$ to $\left.3^{\prime}\right)$ & NCBI sequence \\
\hline ACTB & Forward & CTGGACTTCGAGCAGGAGAT & AY141970 \\
& Reverse & GATGTCGACGTCACACTTC & NM_174366 \\
ISG15 & Forward & GGTATCCGAGCTGAAGCAGTT & \\
& Reverse & ACCTCCCTGCTGTCAAGGT & NM_001040516 \\
RPL19 & Forward & ATTGACCGCCACATGTATCA & \\
& Reverse & GCGTGCTTCCTTGGTCTTAG & BC105539 \\
& Forward & TTCTCCCCAGAAAGCAGCAA & \\
& Reverse & TTCACAGTTGGCCTTGTCATG & \\
\hline
\end{tabular}

34 were reexamined for pregnancy by transrectal palpation 4 wk later, on d $62 \pm 3$ of gestation. Pregnancy per AI was calculated by dividing the number of cows diagnosed as pregnant at $34 \pm 3$ or $62 \pm 3 \mathrm{~d}$ after AI by the number of cows receiving AI. Pregnancy loss was calculated as the number of cows that lost a pregnancy between d $34 \pm 3$ and $62 \pm 3$ after AI divided by the number of cows diagnosed pregnant on d $34 \pm 3$ after AI. Cows detected in estrus before pregnancy diagnosis were reinseminated and considered as nonpregnant.

\section{BCS and Milk Yield}

The body condition of all cows was scored on study d 4 according to Ferguson et al. (1994) using the Elanco BCS chart (Elanco Animal Health, 2009). For statistical analysis, BCS was categorized as low when BCS $\leq 2.75$ or moderate when BCS $\geq 3.00$. Yields of milk were recorded for individual cows once monthly using on-farm milk meters (Tru-Test Ltd., Manukau, New Zealand). The production on the month of insemination was categorized as above or below the mean milk yield within primiparous and multiparous cows in the study and were included in the statistical models for data analyses.

\section{Statistical Analysis}

Categorical data were analyzed by logistic regression using the GLIMMIX procedure of SAS version 9.3 (SAS/STAT, SAS Institute Inc., Cary, NC) fitting a binary distribution. The models included the fixed effects of treatment, parity, type of AI, BCS category, number of AI (first AI vs. resynchronized AI), categorized milk yield within parity in the month of $\mathrm{AI}$ as above or below the mean value, the interactions between treatment and parity, treatment and type of AI, and treatment and number of AI, as well as the random effect of block. For P/AI and pregnancy loss, the fixed effects of sire and technician were also included in the models. The Kenward-Roger method was used to calculate the denominator degrees of freedom to approximate the $\mathrm{F}$ tests in the mixed models. Model fitting was evaluated using the fit statistics. The estimates were back-transformed using the ILINK function of SAS to generate the adjusted proportions. An additional analysis of pregnancy on d 34 was performed in the 240 cows with progesterone concentrations on d 8 after AI to model the effect of progesterone concentration on P/AI. The model included the fixed effects of treatment, progesterone concentration on d 8 as a linear or quadratic term, and the random effect of block. The logistic function was used to model the probability of pregnancy as a function of progesterone concentration.

Continuous data with repeated measures over time were analyzed using the GLIMMIX procedure of SAS with models fitting a Gaussian distribution. Data were tested for normality of residuals, and data with residuals not normally distributed were transformed before analysis. The models included the fixed effects of treatment, day of measurement, parity, type of AI, interactions between treatment and day, treatment and parity, treatment and type of AI, and treatment and number of AI, as well as the random effects of cows nested within treatment and block. The effect of pregnancy on d 34 and the interaction between treatment and pregnancy on d 34 were also included for the analysis of progesterone concentrations in plasma. When the Ftest for an interaction was significant, means were then partitioned using the SLICE command in SAS. The covariance structure that resulted in the smallest Akaike's information criterion was selected for the model. When time intervals between measurements were unequal, then the spatial power covariance structure was used. Model fitting was evaluated using the fit statistics.

Quantitative PCR data are presented using the comparative method developed by Livak and Schmittgen (2001) using nonpregnant cows from the control group as the reference for relative expression of mRNA abundance, which was set to the relative value of 1 . The delta cycle threshold $\left(\boldsymbol{\Delta} \mathbf{C}_{\mathbf{T}}\right)$ values for each target gene were obtained after normalization of $\mathrm{C}_{\mathrm{T}}$ value of the gene with the geometric mean of $\mathrm{C}_{\mathrm{T}}$ values from the 2 reference genes according to Vandesompele et al. 
(2002). Data were analyzed using the $\Delta \mathrm{C}_{\mathrm{T}}$ for $\mathrm{d} 16$ or 19 with the Mixed procedure of SAS fitting a model with the fixed effects of treatment, pregnancy on d 34, and the interaction between treatment and pregnancy on $\mathrm{d} 34$ and the random effect of block. The $\Delta \Delta \mathrm{C}_{\mathrm{T}}$ were obtained from $\Delta \mathrm{C}_{\mathrm{T}} \mathrm{LSM}$ differences of pairwise comparisons among treatments and the reference group control nonpregnant cows (Yuan et al., 2006). The relative expression values were obtained by raising the PCR amplification efficiency $(\mathrm{E}=2)$ to the power $\Delta \Delta \mathrm{C}_{\mathrm{T}}$ (Yuan et al., 2006). Confidence limits for graphical representation of relative expression were generated from the lower and upper CI obtained for $\Delta \mathrm{C}_{\mathrm{T}} \mathrm{LSM}$ differences as described by Yuan et al. (2006).

Orthogonal comparisons were used to determine the effects of supplementing progesterone with CIDR (control vs. CIDR $4+$ CIDR4+7) and the effects of amount of progesterone supplemented (CIDR4 vs. CIDR4+7). Contrasts for the interactions between type of $\mathrm{AI}$ and supplemental progesterone or the amount of supplemental progesterone were also tested. Differences with $P \leq 0.05$ were considered significant and those with $0.05<P \leq 0.10$ were considered tendencies.

\section{RESULTS}

Of the 504 CIDR 4 cows, 19 lost the insert before d 18 of the study $(3.8 \%)$. Of the 495 CIDR $4+7$ cows, 28 lost at least 1 insert (5.6\%), of which 20 lost a single insert $(4.0 \%)$ and 8 lost both inserts $(1.6 \%)$ before $\mathrm{d}$ 18. Twelve of the 1,498 initially enrolled cows were excluded from the data analyses (4 control, 4 CIDR4, 4 CIDR4+7) because of errors during treatment administration or because they received another AI on study d 4, concurrent with treatment administration. Another 18 cows were excluded from the analysis of $\mathrm{P} / \mathrm{AI}$ because they either died or were sold before the day of pregnancy diagnosis. Therefore, of the initial 1,498 cows, 1,468 were used for statistical analyses of the data.

Milk yield on the month of enrollment did not differ $(P=0.47)$ among treatments and averaged $38.3 \pm 0.5$, $39.0 \pm 0.5$, and $38.2 \pm 0.5 \mathrm{~kg} / \mathrm{d}$ for control, CIDR4, and CIDR4 +7 , respectively. Multiparous cows had greater $(P<0.01)$ milk production than primiparous cows $(41.9 \pm 0.4$ vs. $35.1 \pm 0.5 \mathrm{~kg} / \mathrm{d})$. No difference in milk yield was observed for cows inseminated in estrus or timed AI and averaged $38.5 \mathrm{~kg} / \mathrm{d}$. The DIM at AI for all cows in the study did not differ $(P=0.66)$ among treatments and averaged $114.7 \pm 2.1,114.9 \pm 2.1$, and $117.0 \pm 2.1$ for control, CIDR4, and CIDR4+7, respectively. The proportions of control, CIDR4, and CIDR4 +7 cows receiving first and resynchronized AI, respectively, were 32.5 and $67.5,35.5$ and 64.5 , and 34.7 and $65.4 \%$. The mean and median numbers of AI for cows enrolled in the study were $2.7 \pm 0.1$ and 2.0, and both did not differ among treatments. The median BCS of cows in the study was less $(P=0.04)$ for control than CIDR 4 and CIDR $4+7$ (2.75 vs. 3.00 vs. 3.00$)$. Because of this difference in median BCS, a tendency $(P=0.08)$ was observed for more control cows to have BCS $<3.00$ compared with cows receiving CIDR4 and CIDR4+7 (50.7 vs. 43.9 vs. $46.8 \%$ ).

\section{Concentrations of Progesterone and Luteolysis by 19}

Mean concentrations of progesterone in the 20 blocks of cows sampled throughout the treatment period increased $(P<0.02)$ with supplemental progesterone, but only a numerical increase was observed between means for the CIDR4 and CIDR4+7 (Figure 2). As anticipated, concentrations of progesterone did not differ among treatments on $\mathrm{d} 4$. Inclusion of a CIDR in CIDR 4 and CIDR4+7 on d 4 after AI increased concentrations of progesterone by approximately $2.2 \mathrm{ng} /$ $\mathrm{mL}$ on $\mathrm{d} 5,1 \mathrm{~d}$ after treatment. The inclusion of a second progesterone insert in CIDR $4+7$ on $\mathrm{d} 7$ resulted in an additional increment in progesterone concentrations of approximately $1.2 \mathrm{ng} / \mathrm{mL}$ on $\mathrm{d} 8$ compared with CIDR4. Concentrations of progesterone increased $(P<0.001)$ per day after AI until it reached a peak on d 16, after which it slightly declined, particularly in the progesterone-supplemented cows. No difference in progesterone concentrations was observed among treatments after d 16 of the study. Milk yield or BCS were not associated with concentrations of progesterone between $\mathrm{d} 5$ and 18 after AI.

From the subset of 240 cows sampled for blood on d 8, 16, and 19, effects of treatment $(P=0.002)$, day $(P<0.001)$, interaction between treatment and day $(P$ $<0.001)$, and pregnancy $(P<0.001)$ were observed for concentrations progesterone (Figure 3). For cows eventually diagnosed pregnant on d 34 (Figure 3A), concentrations in plasma increased $(P<0.05)$ with supplemental progesterone and with level of supplemental progesterone on d 8 and 16 of gestation. By d 19, after removal of the CIDR, no differences in progesterone concentrations were observed according to treatments. However, for cows eventually diagnosed as nonpregnant on d 34 (Figure 3B), concentrations in plasma increased $(P<0.05)$ with level of supplemental progesterone and with supplemental progesterone only on d 8 after AI. On d 19, after removal of the intravaginal inserts, concentrations of progesterone were less for cows receiving CIDR4 and CIDR4+7 compared with controls. Milk yield or BCS were not associated with concentrations of progesterone on d 8, 16, or 19 after AI. 


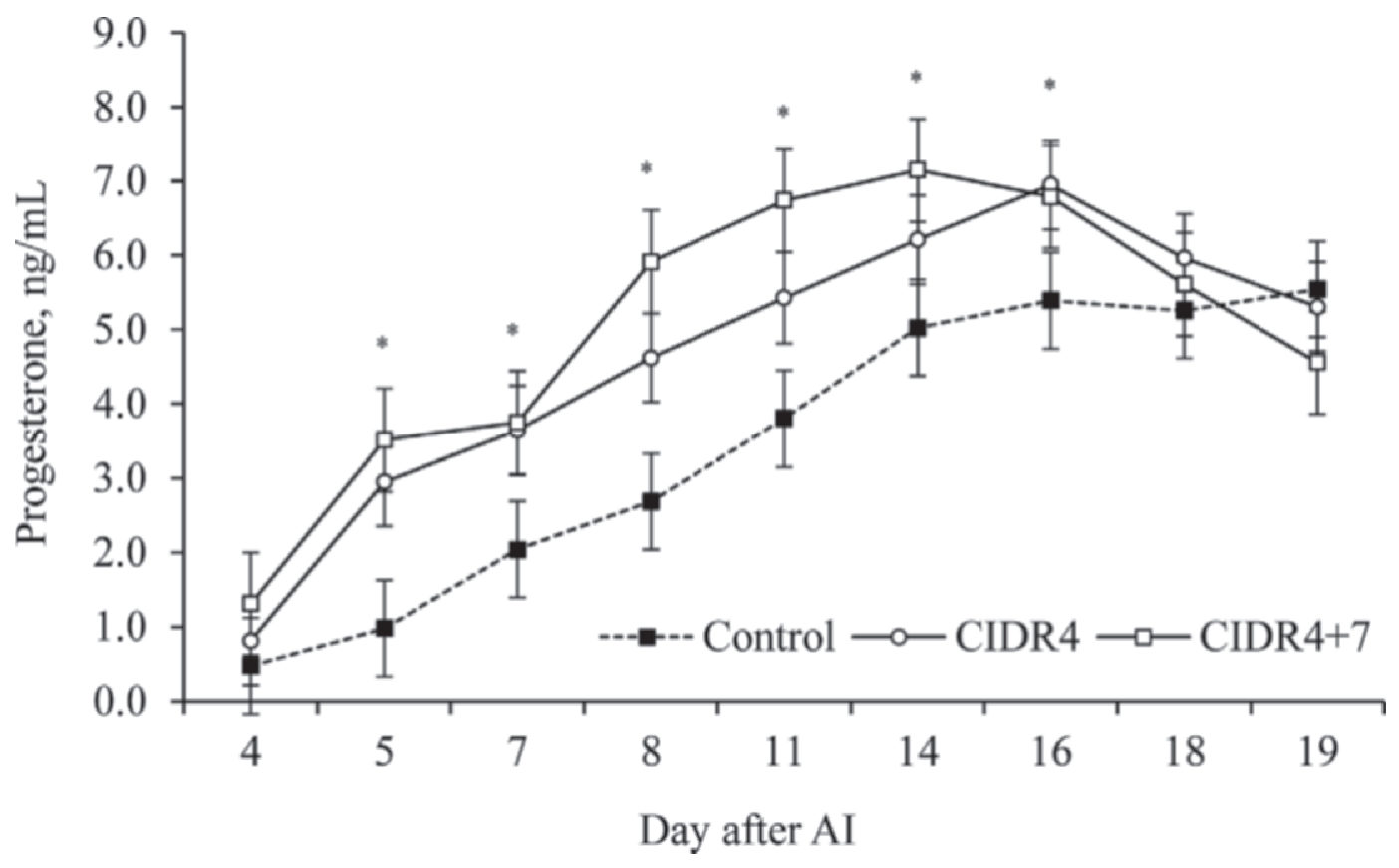

Figure 2. Concentrations of progesterone in plasma according to day after AI. Control $=$ cows received no supplemental progesterone (n $=20) ;$ CIDR $4=$ cows received a controlled internal drug-release $($ CIDR) insert containing progesterone from d 4 to $18(\mathrm{n}=20) ;$ CIDR $4+7=$ cows received a CIDR insert containing progesterone on d 4 and another on d 7 , and they were both removed on d 18 (n = 19). From d 5 to 18 , concentrations averaged $3.42 \pm 0.59,4.97 \pm 0.53$, and $5.46 \pm 0.64 \mathrm{ng} / \mathrm{mL}$ for control, CIDR4, and CIDR4+7, respectively. We observed effects of treatment $(P=0.05)$, day $(P<0.001)$, and interaction between treatment and day $(P<0.01)$; orthogonal comparisons were used for the effect of supplementing progesterone $(P=0.02)$ and of level of progesterone supplementation $(P=0.56)$. Within a day, an asterisk $(*)$ represents an effect of supplemental progesterone $(P<0.05)$.

Supplementing progesterone tended $(P=0.07)$ to increase the incidence of luteolysis on d 19 after AI (Table 2). In fact, from all nonpregnant cows on d 34, a greater $(P=0.01)$ proportion of progesterone-supplemented cows had undergone luteolysis by $d 19$. Level of progesterone supplementation did not affect the risk of luteolysis by d 19 after AI. Method of AI or interaction between treatment and method of AI did not influence the risk of luteal regression by d 19 (Table 3).

\section{IFN-Stimulated Genes Expression in Leukocytes}

One CIDR $4+7$ cow was removed from the analyses of mRNA abundance for ISG in leukocytes because of incorrect administration of treatment. Of the 173 remaining cows, the number of nonpregnant and pregnant cows on d 34 were, respectively, 36 and 22 for controls, 19 and 39 for CIDR4, and 36 and 21 for CIDR4+7.

On d 16 after AI, mRNA abundance for ISG15 was not influenced by supplemental progesterone $(P=$ $0.68)$, level of progesterone supplementation $(P=0.29)$, pregnancy status on $\mathrm{d} 34(P=0.41)$, or interactions between progesterone treatments and pregnancy status (Figure 4A). On the same day, mRNA abundance for $R T P \&$ was not influenced by supplemental progesterone
$(P=0.17)$ or level of progesterone supplementation $(P$ $=0.66)$, but it tended to be less $(P=0.06)$ for pregnant than nonpregnant cows (Figure 4B). No interaction was observed between progesterone and pregnancy $(P=0.45)$ or level of progesterone supplementation and pregnancy $(P=0.54)$.

On d 19 after AI, mRNA abundance for ISG15 tended $(P=0.10)$ to be less for cows supplemented with progesterone than controls, but no difference was observed with level of supplemental progesterone $(P=$ 0.98; Figure 4C). Pregnant cows on d 34 had greater $(P<0.001)$ mRNA abundance for ISG15 than nonpregnant cows. No interaction was observed between progesterone supplementation and pregnancy status on d $34(P=0.43)$ or level of progesterone supplementation and pregnancy $(P=0.43)$. On the same day, mRNA abundance for RTP 4 increased $(P<0.001)$ in pregnant cows, and it was affected by an interaction $(P<0.02)$ between progesterone supplementation and pregnancy status on d 34 (Figure 4D). In pregnant cows, RTP 4 mRNA expression was not influenced $(P$ $=0.81$ ) by progesterone supplementation; however, in nonpregnant cows, supplementation with progesterone reduced $(P<0.01) R T P 4$ gene expression. Level of progesterone supplementation $(P=0.78)$ or interaction 
between level of progesterone and pregnancy status $(P=0.70)$ did not influence $R T P 4$ gene expression in leukocytes on d 19.

\section{Reinsemination in Estrus, P/Al, and Pregnancy Loss}

The proportion of cows reinseminated on estrus before pregnancy diagnosis on d 34 was not affected by supplemental progesterone, but it was greater $(P$ $=0.04$ ) for CIDR4 +7 than CIDR4 (Table 2). When all nonpregnant cows were considered, including those reinseminated on or before $\mathrm{d} 18$, then the interval between pre- and postenrollment AI tended $(P=0.06)$ to be longer for cows supplemented with progesterone, but no effect of level of progesterone supplementation was observed. With the exception of 3 cows in CIDR4 that returned to estrus on or before d 18, the CIDR, as expected, prevented cows from returning to estrus until the removal of the inserts (Figure 5). One cow in CIDR4 lost the CIDR and returned to estrus on $\mathrm{d}$ 15, whereas the other 2 had the CIDR when detected in estrus, 1 on d 13 and another on d 18. Interestingly, when only cows inseminated after d 18 were considered, which coincided with the removal of the intravaginal inserts in CIDR4 and CIDR4+7, the interval between AI was longer $(P=0.02)$ for control cows than for cows supplemented with progesterone.

Pregnancy per AI on d 34 and 62 after insemination did not differ with supplemental progesterone or level of supplementation (Table 2). However, an interaction $(P<0.02)$ between level of supplemental progesterone and method of AI was observed for P/AI on $\mathrm{d}$ 34 and 62 (Table 3). For cows inseminated following detection of estrus, $\mathrm{P} / \mathrm{AI}$ increased with administration of 2 intravaginal inserts in CIDR $4+7$ compared with CIDR4; however, for those inseminated following timed AI, administering a single insert with CIDR4 increased $\mathrm{P} / \mathrm{AI}$. For cows inseminated following timed AI, treatment with a single progesterone insert improved $\mathrm{P} / \mathrm{AI}$ compared with control or CIDR4 4 (Table 3). When data were analyzed with the 240 cows in which plasma was quantified for concentrations of progesterone on d 8 after AI, a quadratic relationship $(P=0.08)$ was observed between progesterone concentration and the probability of pregnancy on d 34. The same analysis was performed separately for cows inseminated after detected estrus or following timed AI (Figure 6). For cows inseminated at detected estrus, the relationship was quadratic $(P=0.09)$; however, for cows receiving timed AI the same relationship was linear $(P<0.001)$. Milk yield or BCS were not associated with $\mathrm{P} / \mathrm{AI}$ on $\mathrm{d}$ 34 or 62 after insemination.

Pregnancy loss between d 34 and 62 of gestation was not influenced by supplemental progesterone or
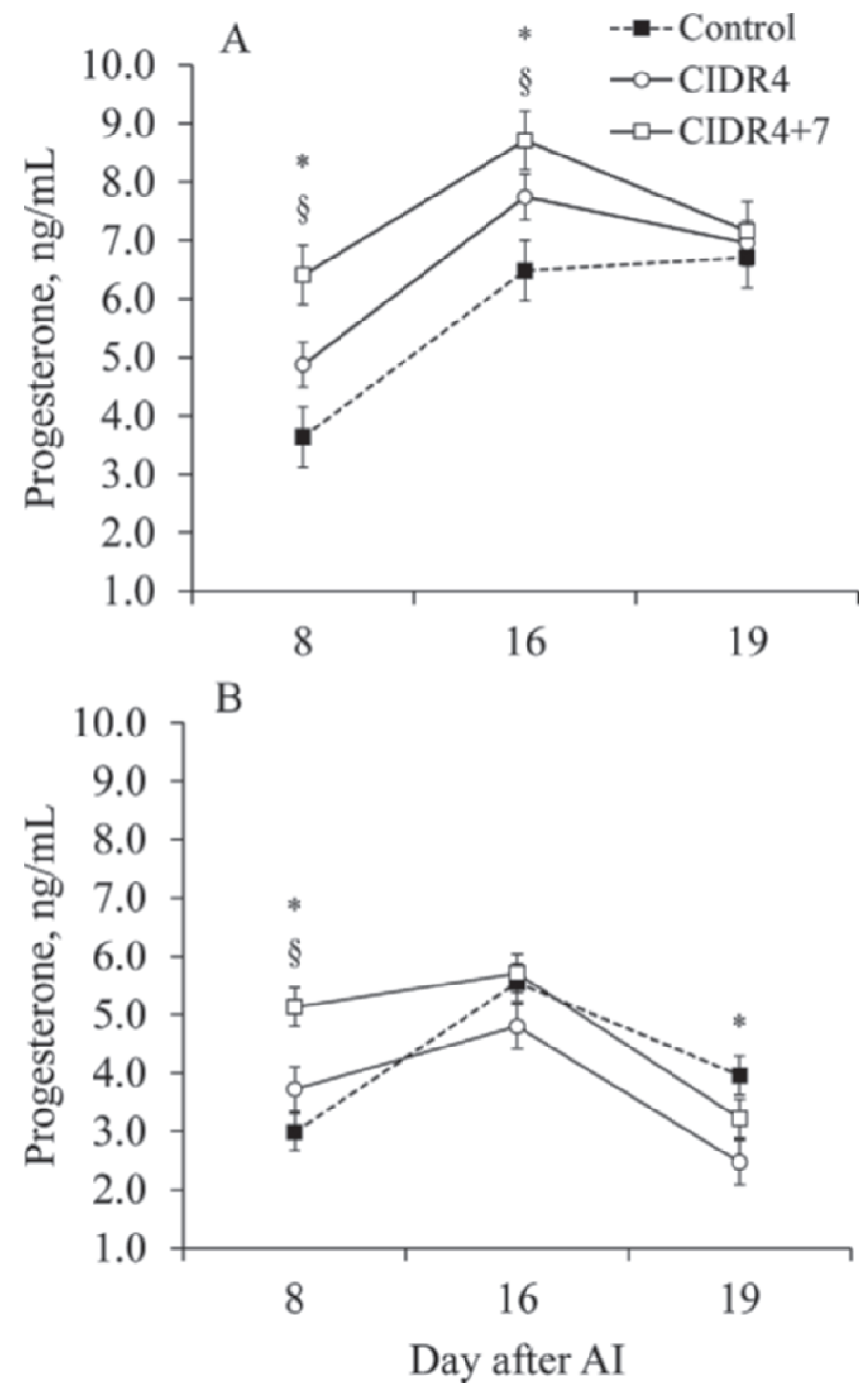

Figure 3. Concentrations of progesterone in plasma of pregnant (A) and nonpregnant (B) cows used for leukocyte isolation and mRNA for IFN-stimulated gene expression $(\mathrm{n}=240)$. Control $=$ cows received no supplemental progesterone $(\mathrm{n}=80) ; \mathrm{CIDR} 4=$ cows received a controlled internal drug-release (CIDR) insert containing progesterone from $\mathrm{d} 4$ to $18(\mathrm{n}=80)$; CIDR $4+7=$ cows received a CIDR insert containing progesterone on $\mathrm{d} 4$ and another on $\mathrm{d} 7$, and they were both removed on d $18(\mathrm{n}=80)$. We observed effects of treatment $(P$ $=0.002)$, day after AI $(P<0.001)$, interaction between treatment and day $(P=0.001)$, and pregnancy $(P<0.001)$; orthogonal comparisons were used for the effects of supplementing progesterone $(P=0.02)$ and amount of progesterone supplemented $(P<0.01)$. Within a day, pairwise differences $(P<0.05)$ are represented as an asterisk $\left(^{*}\right)$ for effect of progesterone supplementation and a symbol $(\S)$ for effect of level of progesterone supplementation.

by the amount of progesterone supplemented to cows (Table 2). Similarly, no interaction was observed between method of AI and supplemental progesterone or amount of progesterone supplemented for pregnancy loss (Table 3). Cows inseminated following detection of 
Table 2. Effect of the supplemental progesterone (P4) after AI on fertility responses in lactating dairy cows

\begin{tabular}{|c|c|c|c|c|c|c|}
\hline Item & \multicolumn{3}{|c|}{ Treatment $^{1}$} & \multicolumn{3}{|c|}{$P$-value ${ }^{2}$} \\
\hline \multicolumn{7}{|l|}{ Luteolysis by d $19,{ }^{3} \%$} \\
\hline Nonpregnant cows & $23.7(11 / 49)$ & $62.5(21 / 39)$ & $45.2(28 / 58)$ & 0.01 & $<0.01$ & 0.21 \\
\hline \multicolumn{7}{|l|}{ Reinsemination in estrus } \\
\hline Reinseminated, ${ }^{4} \%$ & $59.1(195 / 335)$ & $54.6(170 / 319)$ & $63.0(197 / 321)$ & 0.13 & 0.94 & 0.04 \\
\hline \multicolumn{7}{|l|}{ Pregnant, $\%$} \\
\hline d 34 & $30.8(154 / 492)$ & $35.2(172 / 492)$ & $33.2(161 / 484)$ & 0.40 & 0.23 & 0.55 \\
\hline d 62 & $28.6(142 / 492)$ & $32.7(161 / 492)$ & $29.5(145 / 484)$ & 0.39 & 0.37 & 0.31 \\
\hline Pregnancy loss, ${ }^{7} \%$ & $6.5(12 / 154)$ & $6.4(11 / 172)$ & $10.2(16 / 161)$ & 0.41 & 0.58 & 0.25 \\
\hline
\end{tabular}

${ }^{1}$ Control $=$ cows received no supplemental progesterone; CIDR4 $=$ cows received a controlled internal drug-release $($ CIDR) insert containing progesterone from d 4 to 18 ; CIDR $4+7=$ cows received a CIDR insert containing progesterone on $\mathrm{d} 4$ and another on $\mathrm{d} 7$ and they were both removed on d 18; presented as adjusted proportions (n/n) or LSM $( \pm$ SEM).

${ }^{2} \mathrm{TRT}=$ effect of treatment; P4 = orthogonal comparison for the effect of supplemental progesterone (control vs. CIDR4 + CIDR4 +7 ); Level $\mathrm{P} 4=$ orthogonal comparison for level of supplemental progesterone (CIDR4 vs. CIDR4 +7 ).

${ }^{3}$ The proportion of cows sampled for blood on d 19 that had progesterone $<1 \mathrm{ng} / \mathrm{mL}$.

${ }^{4}$ The proportion of nonpregnant cows reinseminated by AI after detected estrus before pregnancy diagnosis at $34 \pm 3 \mathrm{~d}$ after AI.

${ }^{5}$ Interval between AI on study d 0 and reinsemination of cows detected in estrus any day before pregnancy diagnosis on $\mathrm{d} 34$.

${ }^{6}$ Interval between AI on study d 0 and reinsemination of cows detected in estrus after d 18, when CIDR were removed, and before pregnancy diagnosis on $\mathrm{d} 34$.

${ }^{7}$ Pregnancy loss between 34 and $62 \mathrm{~d}$ of gestation.

estrus tended $(P=0.10)$ to have increased pregnancy loss compared with those inseminated following timed AI (10.0 vs. $5.7 \%)$. Milk yield or BCS were not associated with pregnancy loss between gestation d 34 and 62 .

\section{DISCUSSION}

The main hypothesis of the present study was that a progesterone rise after insemination was an important limiting factor for pregnancy in lactating dairy cows. Supplementing progesterone to mimic concentrations that are typically observed in dairy heifers, which were anticipated to lengthen exposure of the conceptus and endometrium to concentrations compatible with those observed during the luteal phase, would increase $\mathrm{P} / \mathrm{AI}$ likely because of stimulation of embryo development. However, supplementing progesterone with intravaginal inserts, which are known to deliver approximately 90 $\mathrm{mg} / \mathrm{d}$ (Rathbone et al., 2002) and increase concentrations in plasma by approximately $1 \mathrm{ng} / \mathrm{mL}$ (Cerri et al., 2009a), had minor effects on the fertility responses of lactating dairy cows.

An additional hypothesis was that the beneficial effects of supplementing progesterone on fertility would be exacerbated in cows inseminated following timed AI. Although properly implemented timed AI protocols result in good to excellent embryo quality (Cerri et al., $2009 b)$, synchronizing ovulation also results in variable size ovulatory follicles (Souza et al., 2007; Santos et al., 2010), and inducing ovulation of small follicles reduces concentrations of progesterone during the subsequent diestrus (Vasconcelos et al., 2001) and P/AI (Perry et al., 2005; Souza et al., 2007). No interaction between supplemental progesterone and method of AI was observed, indicating that exogenous progesterone, as in CIDR4 and CIDR4+7, did not have a differential effect on pregnancy in cows inseminated either on estrus or following timed AI; however, the single insert on d 4 benefited pregnancy in cows inseminated following timed AI. In fact, when only supplemented cows were considered, an interaction between level of progesterone supplementation and method of AI was observed. Within estrus-detected cows, addition of a second progesterone insert with CIDR4+7 numerically increased $\mathrm{P} / \mathrm{AI}$, but for timed AI cows the single insert in CIDR4 resulted in greater $\mathrm{P} / \mathrm{AI}$ than using 2 sequential inserts in CIDR4+7. Perhaps cows inseminated on detected estrus had less incidence of multiple ovulation and had some benefit from increased progesterone supplementation. Conversely, 25 to $30 \%$ of the cows inseminated following timed AI developed the ovulatory follicle under low concentrations of progesterone (Bisinotto et al., 2013), which resulted in more multiple ovulations and, perhaps, less need for larger amounts of supplemental progesterone. Cows inseminated following timed AI or after detected estrus have many distinct physiological differences, including expression of estrus and size of 


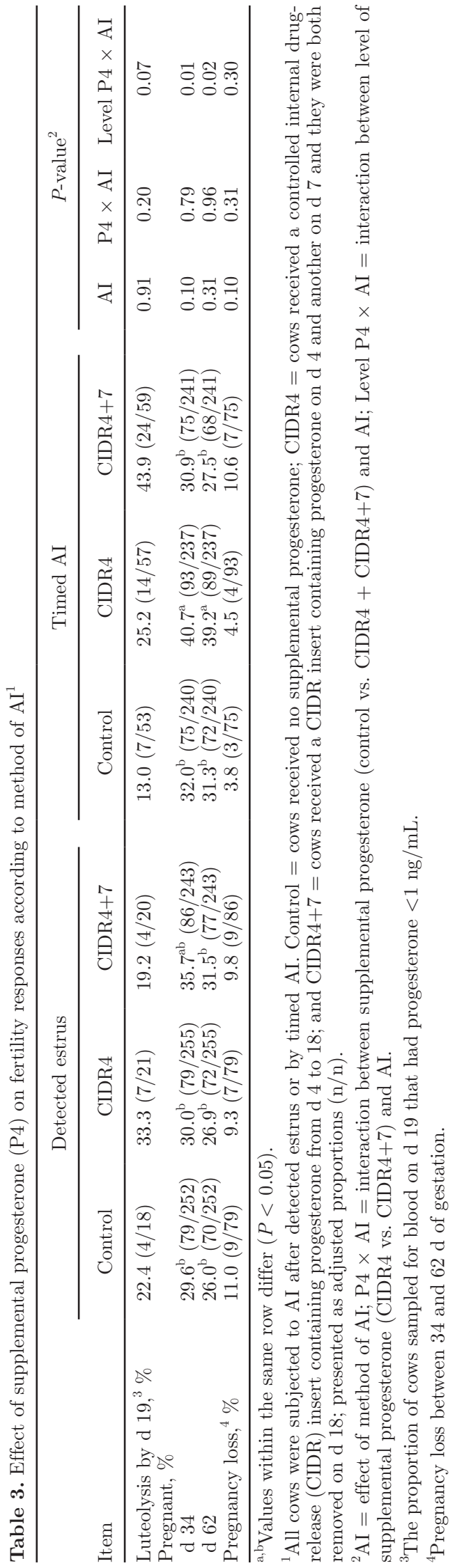

the ovulatory follicle, and it is possible that they are differentially responsive to the 2 methods of progesterone supplementation used in the current study. In general, increments in progesterone concentrations in early diestrus are linked with improved P/AI (Stronge et al., 2005; Parr et al., 2012). In the current study, when all cows were analyzed together, a quadratic association between progesterone on d 8 and pregnancy was observed, as suggested by others in dairy heifers (Parr et al., 2012). Nonetheless, the relationship between progesterone and pregnancy differed slightly when data from cows inseminated on estrus were analyzed separately from those of cows subjected to fixed time AI. For cows inseminated following estrus, a positive quadratic relationship was observed, indicating that P/ $\mathrm{AI}$ increased as progesterone increased, but the benefit declined as concentrations became very high. Conversely, for timed AI cows the relationship was linear, indicating that the incremental benefits of increasing progesterone during diestrus to $\mathrm{P} / \mathrm{AI}$ were similar at all ranges of progesterone concentrations observed.

The rationale for supplementing progesterone starting on d 4 after AI was based on the results from Mann and Lamming (1999), who observed improved $\mathrm{P} / \mathrm{AI}$ when supplementation was initiated during late metestrus or early diestrus, but not after d 6 post-AI. It is thought that lactation, with associated increases in DMI, enhances the catabolism of progesterone by the splanchnic tissues, primarily the liver (Parr et al. 1993; Wiltbank et al., 2011). A reduction in progesterone could limit proper uterine priming and conceptus development (Carter et al., 2008; Clemente et al., 2009), thereby reducing P/AI in dairy cows (Stronge et al., 2005; Parr et al., 2012). Dairy heifers, which are known to have high fertility, have a steeper rise in postovulation progesterone concentrations starting on d 4 after AI compared with lactating dairy cows (Sartori et al., 2004), and the differences in concentrations are approximately $2 \mathrm{ng} / \mathrm{mL}$ starting on d 7 after AI. Nascimento et al. (2013) demonstrated that concurrent use of a CIDR and treatment with $3,300 \mathrm{IU}$ of hCG on d 5 of the estrous cycle resulted in progesterone profiles in lactating dairy cows that were similar to those of dairy heifers; however, the same authors demonstrated that use of a single CIDR or only hCG on d 5 did not result in progesterone profiles in lactating dairy cows that mimic those of heifers. In the current study, addition of a single intravaginal insert in CIDR4 increased progesterone concentrations by approximately $1.5 \mathrm{ng} /$ $\mathrm{mL}$ between $\mathrm{d} 5$ and 18 after $\mathrm{AI}$, and the inclusion of a second insert on $\mathrm{d} 7$ in CIDR $4+7$ resulted in an additional $0.5 \mathrm{ng} / \mathrm{mL}$ increment in progesterone concentration during the same period. When a larger number of cows was evaluated, but only on d 8 and 16 of 

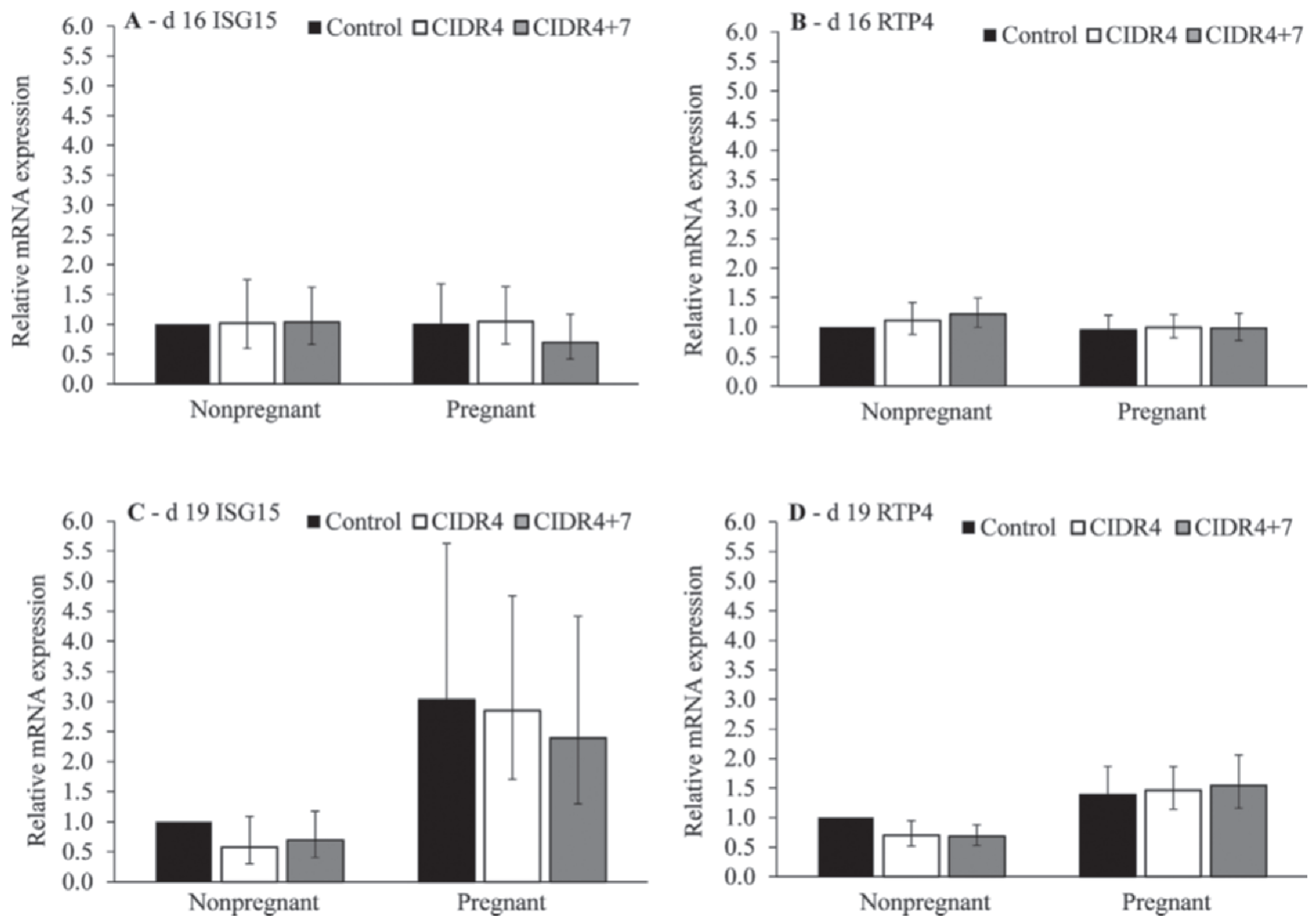

Figure 4. Relative abundance and 95\% CI of mRNA for IFN-stimulated genes (ISG) in leukocytes isolated from cows receiving no supplemental progesterone (control; 36 nonpregnant and 22 pregnant on d 34), a controlled internal drug-release (CIDR) insert containing progesterone from d 4 to 18 (CIDR4; 19 nonpregnant and 39 pregnant on d 34), or a CIDR insert containing progesterone on d 4 and another on d 7 , with both removed on d 18 (CIDR4+7; 36 nonpregnant and 21 pregnant on d 34). Control nonpregnant cows were the reference group for depicting relative mRNA expression. (A) Interferon-stimulated gene 15-kDa protein expression on d 16 after AI; (B) receptor transporter protein-4 expression on d 16 after AI (effect of pregnancy: $P=0.06$ ); (C) $I S G 15$ expression on d 19 after AI (effect of supplemental progesterone: $P=0.10$; effect of pregnancy: $P<0.001$ ); (D) RTP 4 expression on d 19 after AI (effect of supplemental progesterone: $P<0.10$; effect of pregnancy: $P<$ 0.001 ; interaction between supplemental progesterone and pregnancy: $P<0.02$ ).

the study, then progesterone concentrations increased from $4.7 \mathrm{ng} / \mathrm{mL}$ in controls to 5.3 in CIDR4 and to $6.5 \mathrm{ng} / \mathrm{mL}$ in CIDR4+7. Therefore, the increments in progesterone concentrations with addition of the CIDR were compatible with the findings of others in which each insert results in approximately 0.8 to $1.0 \mathrm{ng} / \mathrm{mL}$ additional progesterone in plasma (Cerri et al., 2009a; Bisinotto et al., 2013). Furthermore, the changes in the present study mimic increases in progesterone associated with higher fertility in heifers (Sartori et al., 2004).

Overall, P/AI did not differ between controls and cows supplemented with progesterone, despite the positive association between concentrations on $\mathrm{d} 8$ and pregnancy on d 34. It was thought that supplementing progesterone during metestrus and early diestrus would stimulate endometrial secretion of histotroph, as demonstrated by the advancement in global gene expression of endometrium in beef heifers (Forde et al., 2009). Heifers receiving an intravaginal insert on $\mathrm{d} 3$ of the estrous cycle showed advancements in temporal changes in endometrial gene expression compared with heifers not supplemented with progesterone (Forde et al., 2009). Concentration of progesterone during early to mid-diestrus was associated with changes in endometrial gland ducts (Wang et al., 2007), which likely increased the supply of nutrients for the developing conceptus and accommodated changes for subsequent placentation (Spencer et al., 2007). The changes in endometrial gene expression and consequent alterations in glandular function and histotroph supply were 

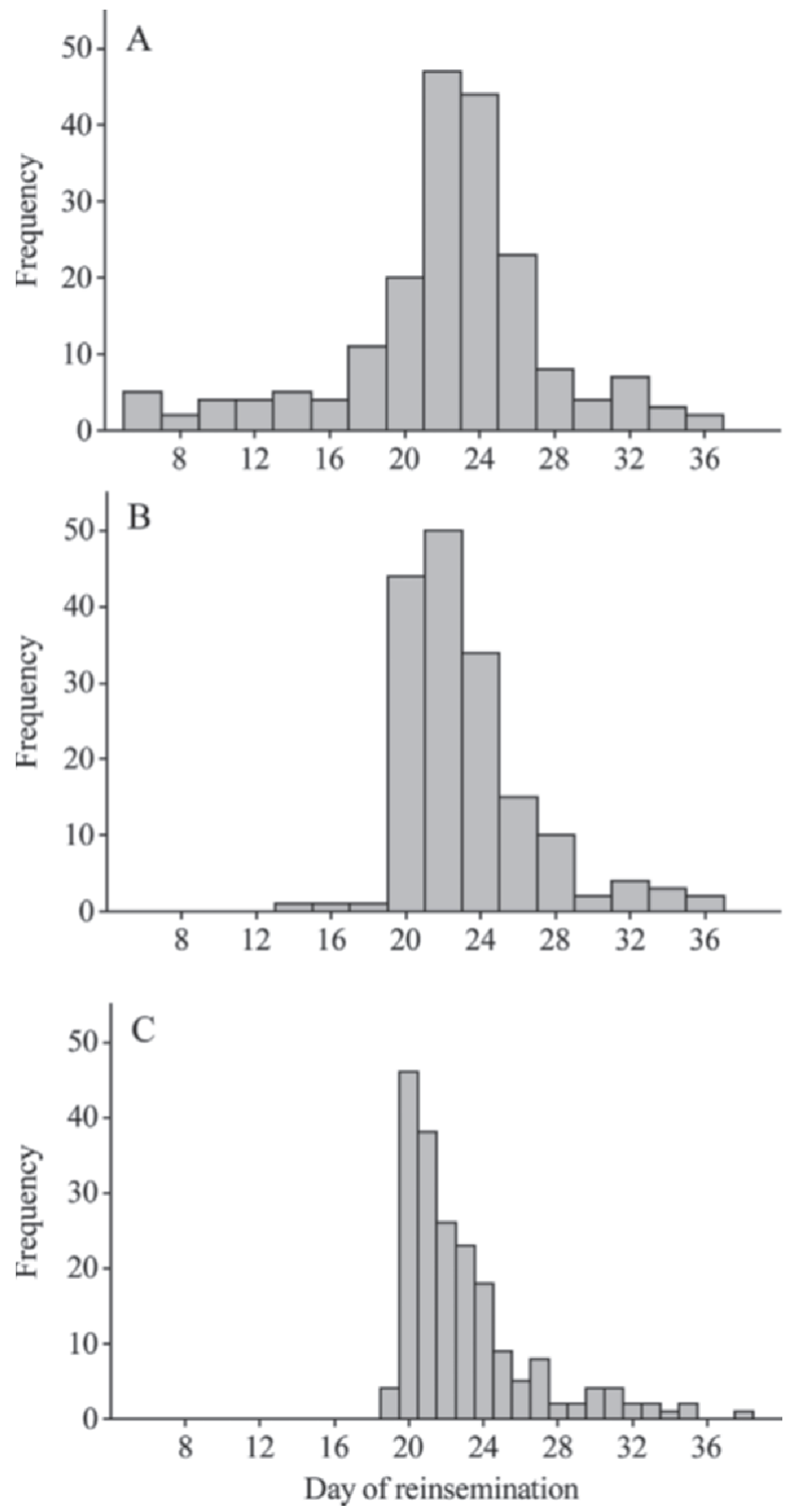

Figure 5. Histogram of day of reinsemination on estrus for control (A; cows received no supplemental progesterone), CIDR4 [B; cows received a controlled internal drug-release (CIDR) insert containing progesterone from d 4 to 18], and CIDR $4+7$ treatment (C; cows received a CIDR insert containing progesterone on $\mathrm{d} 4$ and another on $\mathrm{d}$ 7 and they were both removed on $\mathrm{d} 18$ ).

thought to mediate the advancements in conceptus elongation and changes in embryonic gene expression when heifers had increased concentrations of progesterone (Carter et al., 2008, 2010). Despite the links between progesterone concentrations during early diestrus and fertility in dairy cows, as observed in the

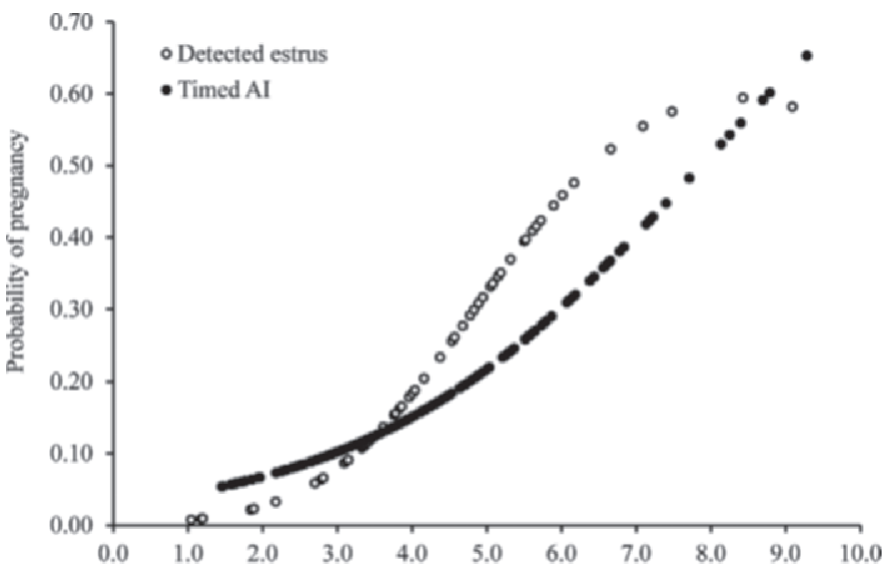

Progesterone on $\mathrm{d} 8$ after $\mathrm{AI}, \mathrm{ng} / \mathrm{mL}$

Figure 6. Probability of pregnancy for cows inseminated following detected estrus $(n=63)$ or after timed AI $(n=177)$ according to concentrations of progesterone in plasma on d 8 after insemination. For cows inseminated upon detected estrus, a quadratic relationship $(P=0.09)$ was observed between concentration of progesterone on $\mathrm{d} 8$ and pregnancy per AI. For cows inseminated following timed AI, the relationship was linear $(P<0.001)$.

current study and demonstrated by others (Parr et al., 2012), increasing concentrations by almost $2 \mathrm{ng} / \mathrm{mL}$ in CIDR 4 and CIDR $4+7$ cows compared with controls did not result in increased $\mathrm{P} / \mathrm{AI}$ or reduced pregnancy loss. Mann and Lamming (1999) reviewed the literature on progesterone supplementation after AI and observed an average of 5-percentage-unit increase in $\mathrm{P} / \mathrm{AI}$. The same authors indicated that most of the benefit of exogenous progesterone was detected when supplementation initiated before d 6 after AI (Mann and Lamming, 1999). Interestingly, Stevenson et al. (2007) also demonstrated an almost 5-percentage-unit increase, from 28.3 to $32.7 \%$, in $\mathrm{P} / \mathrm{AI}$ in dairy cows when receiving supplemental progesterone though CIDR inserts; but, contrary to the findings of Mann and Lamming (1999), all the benefit occurred when the device was inserted after $\mathrm{d} 6$. In the current study, stimulation of $\mathrm{P} / \mathrm{AI}$ with exogenous progesterone was only observed when a single insert was administered on d 4 to cows inseminated following timed AI.

In general, increasing progesterone concentrations early in the estrous cycle stimulates conceptus development (Mann et al., 2006; Carter et al., 2008), which in turn results in increased concentrations of IFN- $\tau$ in the uterine lumen (Mann et al., 2006). Interferon- $\tau$ produced by the trophoblast cells of the conceptus has local effects on the endometrium, but also effects on cells in other tissues (Hicks et al., 2003; Ott and Gifford, 2010). Interferon- $\tau$ exits the uterus and reaches the maternal circulation (Oliveira et al., 2008), which induces expression of genes in blood leukocytes (Gif- 
ford et al., 2008; Oliveira et al., 2008). In fact, mRNA abundance for ISG in leukocytes parallels the concentrations of IFN- $\tau$ in utero (Matsuyama et al., 2012). On d 16, expression of ISG in leukocytes was small and indistinguishable between cows diagnosed nonpregnant and pregnant at $\mathrm{d} 34$. This probably reflected the reduced concentrations of IFN- $\tau$ in utero at that stage of gestation in cows; however, by d 19, mRNA expression increased substantially in pregnant cows. Nevertheless, exogenous progesterone did not increase mRNA expression for ISG in leukocytes on d 16 and 19 after AI. The lack of a positive effect of treatment on ISG in leukocytes might be related to the increase in luteolysis by d 19 in cows that were later found to be nonpregnant. Also, at approximately d 16 of gestation, uterine IFN- $\tau$ in bovine peaks and then declines (Farin et al., 1990). It is possible that the advancements in patterns of endometrial gene expression observed with prolonged exposure to progesterone with supplementation (Forde et al., 2009) might have also advanced the reduction in mRNA expression of IFN- $\tau$ by conceptus trophoblast (Farin et al., 1990) and, therefore, induced an earlier decline in concentrations in utero.

Two concerns with supplementing progesterone during metestrus are the potential interference with CL formation and function or advancement of the luteolytic signals that might induce premature luteolysis. Based on concentrations of progesterone depicted in Figure 3A in pregnant cows on d 19, after treatments had ceased, it is plausible to suggest that CIDR4 and CIDR $4+7$ did not impair the ability of the CL to produce progesterone. Conversely, supplemental progesterone starting during metestrus increased luteolysis on d 19 in nonpregnant cows, which resulted in reduced concentrations of progesterone. These responses in cows later observed to be nonpregnant are likely explained by the advancements in uterine gene expression observed with prolonged progesterone exposure, leading to premature occurrence of luteolysis (Lawson and Cahill, 1983). Treatment of ewes with progesterone shortened the estrous cycle by approximately $4 \mathrm{~d}$ compared with untreated controls (Lawson and Cahill, 1983), which may explain the reductions in pregnancy in heifers supplemented with progesterone within $2 \mathrm{~d}$ after AI (Van Cleeff et al., 1996). Prolonged exposure to progesterone with supplementation in early diestrus may have advanced the peaks of IFN- $\tau$ expression in cows (Farin et al., 1990; Roberts et al., 1999). Increased luteolysis by d 19 in cows later found nonpregnant and potential advancements in peaks of IFN- $\tau$ might have precluded the detection of increments in mRNA expression on d 19 for ISG15 or RTP 4 with progesterone supplementation. Furthermore, it has been suggested that reduced pregnancy around the time of conceptus- endometrium cross-talk probably explains the reductions in gene expression of $R T P 4$ in leukocytes in cows found nonpregnant on $\mathrm{d} 34$.

It is unclear why supplemental progesterone did not result in further stimulation of mRNA expression of ISG in leukocytes of pregnant cows compared with untreated controls. It was thought that pregnant cows would have advanced conceptus development with supplemental progesterone (Carter et al., 2008), and the latter were expected to have an earlier and more robust increment in expression of ISG because of increased IFN- $\tau$ in utero (Matsuyama et al., 2012). The mRNA abundance in blood leukocytes of the 2 genes investigated in the present study were previously described to be associated with improved conceptus development and increased fertility in lactating dairy cows (Ribeiro et al., 2014). Nonetheless, exogenous progesterone might have attenuated some of the effects of IFN- $\tau$ on leukocytes. Addition of progesterone to leukocytes cultured in vitro blunted the effect of IFN- $\alpha$ in stimulating mRNA expression for myxovirus resistance protein A ( $M x A$; Tayel et al., 2013), an ISG of the same family as $M x 1$ typically quantified in leukocytes of cattle (Gifford et al., 2007; Ribeiro et al., 2014). Interferon- $\tau$ and IFN- $\alpha$ are both type I IFN that interact with the same IFN receptor (Roberts et al., 1999). Therefore, it is plausible to suggest that the positive effects of increasing systemic progesterone on conceptus development in CIDR4 and CIDR4 47 were not evident in blood leukocytes because of direct immunomodulation of supplemental progesterone on ISG (Tayel et al., 2013). In fact, responses of blood leukocytes to IFN- $\tau$ during early pregnancy are believed to counter-balance the immunosuppressive effects of progesterone on the maternal immune system (Ott and Gifford, 2010). A study supplementing somatotropin that stimulated conceptus development, without changes in progesterone concentrations, resulted in increased expression of ISG in leukocytes and P/AI in dairy cows (Ribeiro et al., 2014). In the present study, if advanced conceptus development was successfully obtained with exogenous progesterone, as observed by others (Carter et al., 2008; Clemente et al., 2009), then the lack of responses in ISG in blood leukocytes and P/AI brings new insights to the interactions among progesterone concentrations, conceptus development, IFN- $\tau$, and maternal immune system during establishment of pregnancy in dairy cattle.

\section{CONCLUSIONS}

Supplementing progesterone to lactating dairy cows with intravaginal inserts starting on d 4 after AI increased concentrations of progesterone in plasma in a 
dose-dependent manner, but did not increase mRNA expression of IFN-induced genes in leukocytes. Although $\mathrm{P} / \mathrm{AI}$ was associated with concentrations of progesterone on d 8 after insemination, the use of intravaginal inserts to increase progesterone, up to 2 $\mathrm{ng} / \mathrm{mL}$, post-AI did not have an overall beneficial effect on maintenance of pregnancy in lactating dairy cows. When cows were inseminated following timed AI, then a single insert improved P/AI. Furthermore, results indicate that supplemental progesterone during early diestrus increased luteolysis by d 19 in cows found nonpregnant on d 34. Exogenous progesterone supplementation through CIDR was unable to stimulate expression of genes stimulated by IFN, but some benefits were observed in $\mathrm{P} / \mathrm{AI}$ when a single insert was used in cows inseminated following timed AI.

\section{ACKNOWLEDGMENTS}

The authors thank the owner and staff of Alliance Dairies (Trenton, FL) for the use of their cows and facilities. Our appreciation is extended to Nilo Francisco of Alliance Dairies for assistance during the study, and to John Chenault of Zoetis (Madison, NJ) for providing the CIDR inserts. The first author (P. L. J. Monteiro, Jr.) was supported by a scholarship from the São Paulo Research Foundation (Fundação de Amparo a Pesquisa do Estado de São Paulo, São Paulo, Brazil).

\section{REFERENCES}

Bisinotto, R. S., E. S. Ribeiro, F. S. Lima, N. Martinez, L. F. Greco, L. Barbosa, P. P. Bueno, L. F. S. Scagion, W. W. Thatcher, and J. E. P. Santos. 2013. Targeted progesterone supplementation improves fertility in lactating dairy cows without a corpus luteum at the initiation of the timed artificial insemination protocol. J. Dairy Sci. 96:2214-2225

Carter, F., N. Forde, P. Duffy, M. Wade, T. Fair, M. A. Crowe, A. C. O. Evans, D. A. Kenny, J. F. Roche, and P. Lonergan. 2008. Effect of increasing progesterone concentration from day 3 of pregnancy on subsequent embryo survival and development in beef heifers. Reprod. Fertil. Dev. 20:368-375.

Carter, F., F. Rings, S. Mamo, M. Holker, A. Kuzmany, U. Besenfelder, V. Havlicek, J. P. Mehta, D. Tesfaye, K. Schellander, and P. Lonergan. 2010. Effect of elevated circulating progesterone on bovine blastocyst developmental and global transcriptome following endoscopic transfer of in vitro produced embryos to the bovine oviduct. Biol. Reprod. 83:707-719.

Cerri, R. L. A., H. M. Rutigliano, R. G. S. Bruno, and J. E. P. Santos. 2009a. Progesterone concentration, follicular development and induction of cyclicity in dairy cows receiving intravaginal progesterone inserts. Anim. Reprod. Sci. 110:56-70.

Cerri, R. L. A., H. M. Rutigliano, R. C. Chebel, and J. E. P. Santos. 2009b. Period of dominance of the ovulatory follicle influences embryo quality in lactating dairy cows. Reproduction 137:813-823.

Clemente, M., J. de la Fuente, T. Fair, A. Al Naib, A. Gutierrez-Adan, J. F. Roche, D. Rizos, and P. Lonergan. 2009. Progesterone and conceptus elongation in cattle: A direct effect on the embryo or an indirect effect via the endometrium? Reproduction 138:507-517.

Elanco Animal Health. 2009. The 5-point body condition scoring system. Bulletin AI 10752. Elanco Animal Health, Greenfield, IN.
Farin, C. E., K. Imakawa, T. R. Hansen, J. J. McDonnell, C. N. Murphy, P. W. Farin, and R. M. Roberts. 1990. Expression of trophoblastic interferon genes in sheep and cattle. Biol. Reprod. 43:210-218.

Ferguson, J. D., D. T. Galligan, and N. Thomsen. 1994. Principal descriptors of body condition score in Holstein cows. J. Dairy Sci. 77:2695-2703

Forde, N., F. Carter, T. Fair, M. A. Crowe, A. C. O. Evans, T. E. Spencer, F. W. Bazer, R. McBride, M. P. Boland, P. O'Gaora, P. Lonergan, and J. F. Roche. 2009. Progesterone-regulated changes endometrial gene expression contribute to advanced conceptus development in cattle. Biol. Reprod. 81:784-794.

Gifford, C. A., A. M. Assiri, M. C. Satterfield, T. E. Spencer, and T. L. Ott. 2008. Receptor transporter protein 4 (RTP4) in endometrium, ovary, and peripheral blood leukocytes of pregnant and cyclic ewes. Biol. Reprod. 79:518-524.

Gifford, C. A., K. Racicot, D. S. Clark, K. J. Austin, T. R. Hansen M. C. Lucy, C. J. Davies, and T. L. Ott. 2007. Regulation of interferon-stimulated genes in peripheral blood leukocytes in pregnant and bred, nonpregnant dairy cows. J. Dairy Sci. 90:274-280.

Hicks, B. A., S. J. Etter, K. G. Carnahan, M. M. Joyce, A. A. Assiri, S. J. Carling, K. Kodali, G. A. Johnson, T. R. Hansen, M. A. Mirando, G. L. Woods, D. K. Vanderwall, and T. L. Ott. 2003. Expression of the uterine Mx protein in cyclic and pregnant cows, gilts, and mares. J. Anim. Sci. 81:1552-1561.

Lawson, R. A. S., and L. P. Cahill. 1983. Modification of the embryo maternal relationship in ewes by progesterone treatment early in the estrous-cycle. J. Reprod. Fertil. 67:473-475.

Livak, K. J., and T. D. Schmittgen. 2001. Analysis of relative gene expression data using real-time quantitative PCR and the $2^{-\triangle \Delta \mathrm{CT}}$ method. Methods 25:402-408.

Mann, G. E., M. D. Fray, and G. E. Lamming. 2006. Effects of time of progesterone supplementation on embryo development and interferon-tau production in the cow. Vet. J. 171:500-503.

Mann, G. E., and G. E. Lamming. 1999. The influence of progesterone during early pregnancy in cattle. Reprod. Domest. Anim. $34: 269-274$.

Matsuyama, S., T. Kojima, S. Kato, and K. Kimura. 2012. Relationship between quantity of IFNT estimated by IFN-stimulated gene expression in peripheral blood mononuclear cells and bovine embryonic mortality after AI or ET. Reprod. Biol. Endocrinol. 10:21.

Meyer, M. D., P. J. Hansen, W. W. Thatcher, M. Drost, L. Badinga, R. M. Roberts, J. Li, T. L. Ott, and F. W. Bazer. 1995. Extension of corpus luteum lifespan and reduction of uterine secretion of prostaglandin $\mathrm{F}_{2 \alpha}$ cows in response to recombinant interferon-tau. J. Dairy Sci. 78:1921-1931.

Nascimento, A. B., A. H. Souza, J. N. Guenther, F. P. Dalla Costa, R. Sartori, and M. C. Wiltbank. 2013. Effects of treatment with human chorionic gonadotrophin or intravaginal progesterone-releasing device after AI on circulating progesterone concentrations in lactating dairy cows. Reprod. Fertil. Dev. 25:818-824.

NRC. 2001. Nutrient Requirements of Dairy Cattle. 7th rev. ed. Washington, DC

Oliveira, J. F., L. E. Henkes, R. L. Ashley, S. H. Purcell, N. P. Smirnova, D. N. R. Veeramachaneni, R. V. Anthony, and T. R. Hansen. 2008. Expression of interferon (IFN)-stimulated genes in extrauterine tissues during early pregnancy in sheep is the consequence of endocrine IFN-tau release from the uterine vein. Endocrinology 149:1252-1259.

Ott, T. L., and C. A. Gifford. 2010. Effects of early conceptus signals on circulating immune cells: Lessons from domestic ruminants. Am. J. Reprod. Immunol. 64:245-254.

Parr, M. H., M. P. Mullen, M. A. Crowe, J. F. Roche, P. Lonergan, A C. O. Evans, and M. G. Diskin. 2012. Relationship between pregnancy per artificial insemination and early luteal concentrations of progesterone and establishment of repeatability estimates for these traits in Holstein-Friesian heifers. J. Dairy Sci. 95:2390-2396.

Parr, R. A., I. F. Davis, M. A. Miles, and T. J. Squires. 1993. Liver blood flow and metabolic clearance rate of progesterone in sheep. Res. Vet. Sci. 55:311-316. 
Perry, G. A., M. F. Smith, M. C. Lucy, J. A. Green, T. E. Parks, M. D. MacNeil, A. J. Roberts, and T. W. Geary. 2005. Relationship between follicle size at insemination and pregnancy success. Proc. Natl. Acad. Sci. USA 102:5268-5273.

Rathbone, M. J., C. R. Bunt, C. R. Ogle, S. Burggraaf, K. L. Macmillan, C. R. Burke, and K. L. Pickering. 2002. Reengineering of a commercially available bovine intravaginal insert (CIDR insert) containing progesterone. J. Control Release 85:105-115.

Ribeiro, E. S., R. G. S. Bruno, A. M. Farias, J. A. Hernández-Rivera, G. C. Gomes, R. Surjus, L. F. V. Becker, A. Birt, T. L. Ott, J. R. Branen, R. G. Sasser, D. H. Keisler, W. W. Thatcher, T. R. Bilby, and J. E. P. Santos. 2014. Low doses of bovine somatotropin enhance conceptus development and fertility in lactating dairy cows. Biol. Reprod. 90:10-12.

Roberts, R. M., A. D. Ealy, A. P. Alexenko, C.-S. Han, and T. Ezashi. 1999. Trophoblast interferons. Placenta 20:259-264.

Santos, J. E. P., C. D. Narciso, F. Rivera, W. W. Thatcher, and R. C. Chebel. 2010. Effect of reducing the period of follicle dominance in a timed artificial insemination protocol on reproduction of dairy cows. J. Dairy Sci. 93:2976-2988.

Sartori, R., J. M. Haughian, R. D. Shaver, G. J. M. Rosa, and M. C. Wiltbank. 2004. Comparison of ovarian function and circulating steroids in estrous cycles of Holstein heifers and lactating cows. J. Dairy Sci. 87:905-920.

Souza, A. H., A. Gumen, E. P. B. Silva, A. P. Cunha, J. N. Guenther, C. M. Peto, D. Z. Caraviello, and M. C. Wiltbank. 2007. Supplementation with estradiol-17 $\beta$ before the last gonadotropinreleasing hormone injection of the Ovsynch protocol in lactating dairy cows. J. Dairy Sci. 90:4623-4634.

Spencer, T. E., G. A. Johnson, F. W. Bazer, R. C. Burghardt, and M. Palmarini. 2007. Pregnancy recognition and conceptus implantation in domestic ruminants: Roles of progesterone, interferons and endogenous retroviruses. Reprod. Fertil. Dev. 19:65-78.

Stevenson, J. S., M. A. Portaluppi, D. E. Tenhouse, A. Lloyd, D. R. Eborn, S. Kacuba, and J. M. DeJarnette. 2007. Interventions after artificial insemination: Conception rates, pregnancy survival, and ovarian responses to gonadotropin-releasing hormone, human chorionic gonadotropin, and progesterone. J. Dairy Sci. 90:331-340.

Stronge, A. J. H., J. M. Sreenan, M. G. Diskin, J. F. Mee, D. A. Kenny, and D. G. Morris. 2005. Post-insemination milk progesterone concentration and embryo survival in dairy cows. Theriogenology 64:1212-1224.

Tayel, S. S., A. A. Helmy, R. Ahmed, G. Esmat, N. Hamdi, and A. I. Abdelaziz. 2013. Progesterone suppresses interferon signaling by repressing TLR-7 and MxA expression in peripheral blood mononuclear cells of patients infected with hepatitis $\mathrm{C}$ virus. Arch. Virol. 158:1755-1764.

Van Cleeff, J., K. L. Macmillan, M. Drost, M. C. Lucy, and W. W. Thatcher. 1996. Effects of administering progesterone at selected intervals after insemination of synchronized heifers on pregnancy rates and resynchronization of returns to service. Theriogenology 46:1117-1130.

Vandesompele, J., K. De Preter, F. Pattyn, B. Poppe, N. Van Roy, A. De Paepe, and F. Speleman. 2002. Accurate normalization of real-time quantitative RT-PCR data by geometric averaging of multiple internal control genes. Genome Biol. 3:RESEARCH34.

Vasconcelos, J. L. M., R. Sartori, H. N. Oliveira, J. G. Guenther, and M. C. Wiltbank. 2001. Reduction in size of the ovulatory follicle reduces subsequent luteal size and pregnancy rate. Theriogenology 56:307-314.

Wang, C. K., R. S. Robinson, A. P. Flint, and G. E. Mann. 2007. Quantitative analysis of changes in endometrial gland morphology during the bovine oestrous cycle and their association with progesterone levels. Reproduction 134:365-371.

Wiltbank, M. C., A. H. Souza, P. D. Carvalho, R. W. Bender, and A. B. Nascimento. 2011. Improving fertility to timed artificial insemination by manipulation of circulating progesterone concentrations in lactating dairy cattle. Reprod. Fertil. Dev. 24:238-243.

Yuan, J. S., A. Reed, F. Chen, and C. N. Stewart. 2006. Statistical analysis of real-time PCR data. BMC Bioinformatics 7:85. 